\title{
Effect of Pharmacological Agents and Fasting on Pancreatic Islet Norepinephrine in the Golden Hamster
}

\author{
J. M. Feldman, J. H. Henderson, and J. A. Blalock \\ Durham Veterans Administration Medical Center and Division of Endocrinology, Department of Medicine, \\ Duke University Medical Center, Durham, North Carolina, USA
}

\begin{abstract}
Summary. Using a specific and sensitive radioenzymatic assay that utilizes the partially purified enzyme phenylethanolamine - $\mathrm{N}$ - methyltransferase, studies were done to determine if pharmacological agents and/or fasting alter the norepinephrine concentration of collagenase-isolated golden hamster pancreatic islets. The norepinephrine concentration (42.1 \pm $8.07 \mu \mathrm{mol} / \mathrm{kg}$ net weight, mean $\pm \mathrm{SEM}$ ) and the monoamine oxidase activity $(5,407 \pm 530$ pmol product $/ \mathrm{mg}$ tissue $/ \mathrm{min}$ ) of hamster pancreatic islets was at least five times higher than acinar pancreas, kidney, heart, median eminence or cerebral cortex. The catechol-o-methyltransferase activity of hamster islets $(7 \pm 2.3 \mathrm{pmol}$ product $/ \mathrm{mg}$ tissue $/ \mathrm{min}$ ) was one half or less than the other tissues. Islet norepinephrine was not increased by two days administration of the monoamine oxidase inhibitor tranylcypromine. Islet norepinephrine concentration was increased 2-fold by administration of the norepinephrine precursor DL-threo-dihydroxyphenylserine. This increase was enhanced by prior administration of tranylcypromine (3.5-fold) and prevented by prior administration of the decarboxylase inhibitor $\mathrm{N}^{1}$-(DL-seryl)- $\mathrm{N}^{2}$-(2,3,4-trihydroxybenzyl) hydrazine (RO-4-4602). There was a good correlation between the islet norepinephrine concentration and the plasma glucose concentration after pharmacological agents. Reserpine administration markedly depleted the islet norepinephrine concentra tion. Fasting of 24,48 and $72 \mathrm{~h}$ did not alter the norepinephrine concentration in islets and heart. It is concluded that the pancreatic islets of the hamster have an active noradrenergic system, but that islet norepinephrine does not appear to play an important role in the impaired insulin secretion of fasting hamsters.
\end{abstract}

Key words: Monoamine oxidase, catechol-o-methyltransferase, DL-threo-dihydroxyphenylserine, nor- epinephrine, pancreatic islets, reserpine, catecholamines, insulin secretion, fasting.

Recent investigations suggest that intracellular pancreatic islet monoamines may play a significant role in the regulation of insulin secretion in physiological and pathological states [1]. Histochemical studies have shown that the islet cells of many animal species contain intracellular dopamine and/or serotonin [2, 3]. Pharmacological studies demonstrate that exogenous dopamine and serotonin inhibit insulin secretion from hamster pancreas [4]. The pancreatic islets of some species, such as golden hamsters and cats, contain noradrenergic nerves $[3,5]$. In hamster islets, these nerves form a dense peri- and intrainsular network [3]. The noradrenergic nerves contain norepinephrine (NE), a potent inhibitor of in vitro insulin secretion from hamster pancreas [6]. It is not clear if NE is found in the B-cells as well as in the adrenergic nerves.

Investigators have demonstrated histochemically that the islet dopamine content of mice is increased by the administration of the dopamine precursor L3,4-dihydroxyphenylalanine (L-DOPA) and that the islet serotonin content of mice is increased by the administration of the serotonin precursor 5-hydroxytryptophan $[3,7]$. The increase in islet monoamines is enhanced by the prior administration of monoamine oxidase (MAO) inhibitors and blocked by the prior administration of an aromatic amino acid decarboxylase inhibitor.

In the present study, the pancreatic islet NE content was determined with a specific and sensitive radioenzymatic technique. Studies were also done on the effects of a monoamine depleting drug (reser- 
Table 1. Norephinephrine concentration and monoamine oxidase and catechol-o-methyltransferase activity in tissues of the golden hamster

\begin{tabular}{|c|c|c|c|c|c|c|}
\hline & Islets & $\begin{array}{l}\text { Acinar } \\
\text { pancreas }\end{array}$ & Kidney & Heart & $\begin{array}{l}\text { Median } \\
\text { eminence }\end{array}$ & $\begin{array}{l}\text { Cerebral } \\
\text { cortex }\end{array}$ \\
\hline $\begin{array}{l}\text { Norepinephrine concentration } \\
(\mu \mathrm{mol} / \mathrm{kg}) \\
\mathrm{MAO} \text { activity }\end{array}$ & $42.1 \pm \quad 8.1$ & $3.2 \pm 0.4$ & $5.0 \pm 0.9$ & $8.8 \pm 0.5$ & $5.7 \pm 0.6$ & $1.6 \pm 0.1$ \\
\hline $\begin{array}{l}\text { (pmol product/mg tissue/min) } \\
\text { COMT activity }\end{array}$ & $5407 \pm 530.1^{\mathrm{a}}$ & $417 \pm 73.8^{\mathrm{a}}$ & $959 \pm 85.6^{\mathrm{b}}$ & $136 \pm 22.0^{\mathrm{b}}$ & $733 \pm 115.8^{\mathrm{a}}$ & $716 \pm 80.0^{\mathrm{b}}$ \\
\hline (pmol product $/ \mathrm{mg}$ tissue/min) & $7 \pm \quad 2.3^{\mathrm{c}}$ & $62 \pm 13.3^{\mathrm{c}}$ & $714 \pm 61.5^{\mathrm{c}}$ & $17 \pm 0.8^{c}$ & $33 \pm 5.5^{c}$ & $28 \pm 1.9^{c}$ \\
\hline
\end{tabular}

Results are given as mean $\pm \mathrm{SEM}$ of six hamsters

a Tryptamine concentration $0.2 \mathrm{mmol} / \mathrm{l}$

b Tryptamine concentration $1.0 \mathrm{mmol} / 1$

c Substrate concentrations 3,4 dihydroxybenzoic acid $3 \mathrm{mmol} / \mathrm{l}$. SAM $60 \mu \mathrm{mol} / 1$

pine), a MAO inhibitor (tranylcypromine) and the effects of supplying a NE precursor (DL-threodihydroxyphenylserine, DOPS). Results in islets have been compared with the response of other tissues known to contain NE (median eminence, cerebral cortex, heart, and kidney). Previously, pharmacological evidence was presented that an increase in pancreatic islet monoamine activity may play a role in the impaired insulin secretion found in fasting hamsters [8]. In the present study, the NE content of pancreatic islets and myocardium of fasting hamsters was determined.

\section{Materials and Methods}

\section{Materials}

The following chemicals were purchased from commercial sources: L-3,4-dihydroxyphenylalanine (L-DOPA) and DL-threo-dihydroxyphenylserine (DOPS) (Sigma Chemical Co., St. Louis, MO); collagenase, class IV (Worthington Biochemical Co., Freehold, $\mathrm{NJ}$ ); tryptamine bisuccinate (side chain $-2-{ }^{14} \mathrm{C}$ ) with specific activity (spec. act.) of $60 \mathrm{mCi} / \mathrm{mmol}$ and S-adenosyl-L-( ${ }^{3} \mathrm{H}$-methyl)methionine ( ${ }^{3} \mathrm{H}-\mathrm{SAM}$ ) with spec. act. of $7.5 \mathrm{Ci} / \mathrm{mmol}$ (New England Nuclear, Boston, MA); reserpine injection, U. S. P. (Eli Lilly and Co., Indianapolis, IN); and pyrogallic acid (Mallinckrodt Inc., St. Louis, MO).

The following chemicals were gifts: tranylcypromine sulfate (Smith, Kline and French Laboratory, Philadelphia, PA); $\mathrm{N}^{1}-$ (DLseryl)- $\mathrm{N}^{2}(2,3,4-$ trihydroxybenzyl) hydrazine (RO-4-4602) (Hoffmann-LaRoche Co., Nutley, NJ). Male golden hamsters $(100-125 \mathrm{~g})$ were purchased from Engel Laboratory, Inc. (Farmersburg, IN).

\section{Experimental Procedure}

The hamsters had access to food and water until the time of sacrifice. All medications were administered by IP injection. The dose and timing of administration of the drugs prior to sacrifice were: reserpine $0.5 \mathrm{mg} / \mathrm{kg}$ at 72,48 and $24 \mathrm{~h}$; tranylcypromine $25 \mathrm{mg} / \mathrm{kg}$ at 48 and $24 \mathrm{~h} ; \mathrm{RO}-4-4602400 \mathrm{mg} / \mathrm{kg}$ at $2 \mathrm{hr}$; pyrogallic acid $240 \mathrm{mg} / \mathrm{kg}$ at 1.5 and $1 \mathrm{~h}$; and DOPS $120 \mathrm{mg} / \mathrm{kg}$ at $1 \mathrm{~h}$.
The hamsters were sacrificed by decapitation and blood collected into heparin. After sacrifice, the median eminence, right kidney, portions of the left ventricle of the heart, and right cerebral cortex were removed. In some cases, a segment of pancreas was removed. Pancreatic islets were isolated by a modified coliagenase digestion technique [9]. The tissue was digested in Hanks balanced salt solution ( $\mathrm{pH}=7.4$ ) when islet $\mathrm{NE}$ and MAO were determined [10]. When catechol-o-methyltransferase (COMT) was determined, calcium ion was omitted from the final wash as calcium is reported to inhibit COMT [11]. The tissues for NE analysis were homogenized in $0.1 \mathrm{~mol} / \mathrm{l}$ perchloric acid $\left(3^{\circ} \mathrm{C}\right)$ in a groundglass homogenizer. After the homogenate was centrifuged at 400 $\mathrm{Xg}$, the supernatant was analyzed for NE. The tissues for assay for $\mathrm{MAO}$ and COMT were homogenized in $1.1 \%$ potassium chloride. The enzyme assays were done on the total homogenate.

\section{Analytical Methods}

The MAO activity of tissue homogenates was determined with a sensitive radioassay that employed ${ }^{14} \mathrm{C}$-tryptamine as a substrate [12]. The MAO activity was equal to the amount of ${ }^{14} \mathrm{C}$-labelled indoleacetaldehyde and indoleacetic acid formed. These metabolites were isolated by differential solvent extraction and counted in a liquid scintillation counter. The COMT activity was determined by a radioassay method in which COMT transfers a ${ }^{14} \mathrm{C}$-methyl group from ${ }^{14} \mathrm{C} \mathrm{S}$-adenosylmethionine to 3,4-dihydroxybenzoic acid [13]. The ${ }^{14} \mathrm{C}-\mathrm{O}$-methylated benzoate derivative was isolated by differential solvent extraction and counted in a liquid scintillation counter. All measurements were performed in duplicate with two different sized aliquots of homogenate. The substrate concentrations and incubation conditions were selected to give maximal activity. The protein content of the homogenates was determined with a colorimetric method [14]. The spec. act. of the MAO and COMT activity is expressed as pmol product/mg tissue protein/ min of incubation.

The radioenzymatic method for measuring $\mathrm{NE}$ in tissues uses the enzyme phenylethanolamine- $\mathrm{N}$-methyltransferase (PNMT) that was partially purified from fresh bovine adrenal glands [15]. The PNMT transfers a ${ }^{3} \mathrm{H}$-labelled methyl group from ${ }^{3} \mathrm{H}-\mathrm{SAM}$ to $\mathrm{NE}$ in the tissue extracts. Due to differences in the nonradioactive SAM content of different tissues, each sample was quantified by its own internal standard. If the limit of sensitivity is taken as a sample-to-blank ratio of two, the sensitivity of the assay is 0.3 to $0.6 \mathrm{pmol} \mathrm{NE} /$ assay tube. The coefficients of variation are: interassay $11 \%$ and intra-assay $8 \%$. The following cross reactivities were found: epinephrine, dopamine, serotonin, tryptamine and tyramine less than $2 \%$; DOPS, L-DOPA, reserpine, pyrogallic 
Table 2. Effect of pharmacological agents on tissue norepinephrine concentration of the golden hamster

\begin{tabular}{|c|c|c|c|c|c|}
\hline & \multicolumn{5}{|l|}{$\mathrm{NE}(\mu \mathrm{mol} / \mathrm{kg})$} \\
\hline & Islets & Kidney & Heart & $\begin{array}{l}\text { Median } \\
\text { eminence }\end{array}$ & $\begin{array}{l}\text { Cerebral } \\
\text { cortex }\end{array}$ \\
\hline Control & $42.1 \pm 8.1$ & $5.0 \pm 0.9$ & $8.8 \pm 0.5$ & $5.7 \pm 0.6$ & $1.6 \pm 0.1$ \\
\hline Tranylcypromine & $41.6 \pm 9.4$ & $4.7 \pm 0.4$ & $12.6 \pm 2.2$ & $13.8 \pm 2.4^{\mathrm{a}}$ & $1.8 \pm 0.1$ \\
\hline DOPS & $81.9 \pm 11.7^{b}$ & $18.0 \pm 2.7^{\mathrm{a}}$ & $11.4 \pm 0.7$ & $6.0 \pm 1.2$ & $1.7 \pm 0.3$ \\
\hline Tranylcypromine + DOPS & $146.6 \pm 16.9^{\mathrm{b}}$ & $28.1 \pm 4.8^{b}$ & $17.0 \pm 2.9^{\mathrm{a}}$ & $13.1 \pm 1.7^{\mathrm{a}}$ & $2.7 \pm 0.4$ \\
\hline \multicolumn{6}{|l|}{ Tranylcypromine +} \\
\hline RO-4-4602 + DOPS & $15.0,20.0$ & $11.0,7.6$ & $8.4,10.8$ & $11.1,7.5$ & $1.5,3.1$ \\
\hline Reserpine & $<4.0,<4.0$ & $<0.2,<0.2$ & $<0.2,<0.2$ & $<0.2,<0.2$ & $<0.2,<0.2$ \\
\hline
\end{tabular}

a Significantly different from control with $\mathrm{p}<0.05$

b Significantly different from control with $\mathrm{p}<0.01$

NE was determined in tissues of hamsters receiving the NE precursor DL-threo-dihydroxyphenylserine (DOPS) or the NE depleting agent reserpine. Some hamsters were pretreated with the monoamine oxidase inhibitor tranylcypromine and/or the decarboxylase inhibitor RO4-4602. Values are given as the mean \pm SEM of six experiments or as individual results

acid and RO-4-4602, $0 \%$. The wet weight of the islets was calculated on the basis of their protein content being $15 \%$ of their weight wet [16]. The NE content of the tissues was expressed as $\mu \mathrm{mol} / \mathrm{kg}$ wet weight. Plasma glucose was measured with a glucose oxidase method [17].

\section{Statistical Methods}

The data was subjected to analysis of variance [18]. The significance of the differences between mean values was estimated using the single-tailed multiple comparisons test of Scheffe [18]. All data is expressed as the mean \pm SEM, unless otherwise stated.

\section{Results}

Table 1 compares the NE content, MAO activity and COMT activity of hamster pancreatic islets with that in other hamster tissues. The NE content and MAO activity of the pancreatic islets was greater than that of acinar pancreas, kidney, heart, median eminence, and cerebral cortex. Both of these substances were present in islets in 13-times greater amount than in acinar pancreas. The MAO activity of the islets was much greater than even that of hamster liver (1898 \pm $193 \mathrm{pmol}$ product $/ \mathrm{mg}$ tissue $/ \mathrm{min}$ with $1 \mathrm{mmol} / \mathrm{l}$ tryptamine substrate). The COMT activity of the pancreatic islets was lower than that of other tissues including hamster liver $(72 \pm 4 \mathrm{pmol}$ product $/ \mathrm{mg}$ tissue/min). However, with the exception of the kidney, there was much less COMT activity than MAO activity in hamster tissues.

The effects of two days administration of the MAO inhibitor tranylcypromine on tissue NE is shown in Table 2. The dose of tranylcypromine used resulted in the following per cent inhibition of MAO activity: islet $88 \%$, kidney $78 \%$, heart $79 \%$, median eminence $88 \%$, cerebral cortex $64 \%$, and liver $87 \%$. Table 2 shows that tranylcypromine did not increase the NE content of islets, kidney, heart, or cerebral cortex. However, it resulted in a 2.5 -times increase in the NE content of the median eminence.

Table 2 also demonstrates that administration of the NE precursor DOPS resulted in an increase in the NE content of islets and kidney, but did not significantly increase the NE content of heart, median eminence, or cerebral cortex. When DOPS was administered to hamsters pretreated with tranylcypromine, the NE content of islets, kidney, and heart, but not cerebral cortex, was increased over control. There was no additional increase in median eminence NE over that which resulted from the administration of tranylcypromine alone. The NE content from tranylcypromine + DOPS was significantly greater than the NE content from DOPS in islets and median eminence.

Table 2 shows the results when two hamsters that were pretreated with tranylcypromine received the decarboxylase inhibitor RO-4-4602 one $h$ prior to DOPS administration. The decarboxylase inhibitor blocked the DOPS-induced increase in NE in islets, kidney, and heart.

To determine if inhibition of COMT altered the tissue NE concentration, four hamsters were treated with pyrogallic acid. Two of the animals also received DOPS. The animals that received pyrogallic acid manifested methemoglobinaemia [24]. However, the pyrogallic acid neither increased the basal tissue NE concentration, nor augmented the effect of DOPS on tissue NE concentration (data not shown).

Reserpine, an agent that depletes tissue NE and serotonin in rats and other animals, depleted the NE content of hamster tissues to a level below the sensitivity of the assay. The hamsters developed signs of catecholamine depletion, such as ptosis and somnolence. 
Table 3. Effect of fasting on norepinephrine concentration of pancreatic islets and heart of the golden hamster

\begin{tabular}{lll}
\hline & \multicolumn{2}{l}{$\mathrm{NE}(\mu \mathrm{mol} / \mathrm{kg})$} \\
\cline { 2 - 3 } & Islets & Heart \\
\hline Control & $38.3 \pm 5.5$ & $6.9 \pm 0.7$ \\
24 h Fast & $42.2 \pm 5.1$ & $6.3 \pm 0.7$ \\
48 h Fast & $41.0 \pm 5.9$ & $7.5 \pm 0.8$ \\
72 h Fast & $34.1 \pm 4.9$ & $5.5 \pm 0.5$ \\
\hline
\end{tabular}

Each number represents the mean $\pm \mathrm{SEM}$ of tissues from seven golden hamsters

The plasma glucose concentrations in the various groups of animals at the time of sacrifice in $\mathrm{mg} / \mathrm{dl}$ were: control, $104 \pm 8$; tranylcypromine, $114 \pm 6$; DOPS, $232 \pm 12$; tranylcypromine + DOPS, $357 \pm$ 33; and tranylcypromine + RO-4-4602 + DOPS, 150. Thus, the plasma glucose levels of the DOPS and the tranylcypromine + DOPS groups were significantly greater than the control groups; the plasma glucose of the tranylcypromine + DOPS group was greater than that of the DOPS group; and the rise in plasma glucose induced by DOPS administration was markedly attenuated by pretreatment with RO-4-4602.

Table 3 compares the NE content of pancreatic islets and heart in control hamsters and hamsters fasted 24,48 and $72 \mathrm{~h}$. By $72 \mathrm{~h}$ of fasting, the hamsters had lost $20 \%$ of their body weight. Despite this, there was no alteration in the NE content of their islets and heart.

\section{Discussion}

The present study demonstrates that the pancreatic islets of the hamster have a very high concentration of NE $(42.1 \pm 8.07 \mu \mathrm{mol} / \mathrm{kg}$ wet weight $)$. The NE concentration of the islets is approximately 13-fold greater than the NE concentration of the acinar pancreas $(5.0 \pm 8.87 \mu \mathrm{mol} / \mathrm{kg}$ wet weight $)$. Using a different but also highly specific assay based on the conversion of monoamines to dansyl derivatives, Hansen and Hedeskov found a concentration of $22.8 \pm$ $4.2 \mu \mathrm{mol} \mathrm{NE} / \mathrm{kg}$ wet weight in mouse islets [19]. In contrast to the hamster, the acinar pancreas of the mouse had a comparable NE concentration to that of the islets [19]. It is not unexpected that the NE concentration of hamster islets would be higher than that of mouse islets, as hamsters have a richer supply of adrenergic nerves in their islets [2].

There is more MAO activity than COMT activity in the majority of hamster tissues including the pancreatic islets. However, inhibition of MAO by the
MAO inhibitor tranylcypromine resulted in an increase in the NE concentration of the median eminence, but not the islets, kidney, heart or cerebral cortex. This is not without precedent, for the MAO inhibitor pargyline increases the NE concentration in the brain, but not in the heart or liver of mice [20]. This may be due to negative feed back in some tissues; the slight rise in NE after the administration of MAO inhibitors decreases tyrosine hydroxylase activity. The decreased tyrosine hydroxylase activity reduces the synthesis of new NE [21].

Hamster pancreatic islets have substantial aromatic amino acid decarboxylase activity [22]. DOPS, a compound that is decarboxylated to NE [23], was therefore administered to the hamsters. DOPS administration resulted in an increased NE content in peripheral (islets, kidney, heart) but not central nervous (median eminence, cortex) tissues. The DOPS induced increase in NE content was augmented by pretreatment of the hamsters with the MAO inhibitor tranylcypromine and blocked by pretreatment with the decarboxylase inhibitor RO-4-4602.

The threo-isomer of DOPS used in these studies produces a much greater increase in NE in peripheral tissues, such as the heart, than in the brain of rats [23]. In contrast, the erythro-isomer of DOPS produces a much greater increase in the NE content of the brain than the threo-isomer [24]. We did not use the erythro-isomer in this study. However, the present study demonstrates that one can use threoDOPS to selectively increase the NE content of peripheral tissues (including islets) without altering the NE content of the brain. This may allow one to separate peripheral control of intermediary metabolism from the central nervous system control of intermediary metabolism.

DOPS is a specific NE precursor, for the dopamine content of islets and other tissues were not altered by its administration (unpublished observations). In contrast, the dopamine content of pancreatic islets can be increased without altering the NE content by administration of the dopamine precursor L-DOPA [25]. By selectively increasing the type of monoamine in the islets, one may be able to determine the relative importance of these compounds in the regulation of insulin secretion.

With the exception of the kidney, hamster tissues have minimal COMT activity. The COMT activity is particularly low in pancreatic islets. The administration of a dose of pyrogallic acid, that has been shown to inhibit COMT activity in the rat, did not increase the basal tissue NE concentration or potentiate the rise in tissue NE concentration after DOPS in the hamster $[26,27]$. Crout et al. noted no change in the $\mathrm{NE}$ concentration of rat brain or heart after $20 \mathrm{~h}$ of 
pyrogallic acid [26]. They concluded that MAO is the major route for inactivation of tissue $\mathrm{NE}$ while COMT is the major route for inactivation of circulating NE.

To demonstrate that it is possible to decrease the islet NE content as well as increase it, hamsters were treated with reserpine [20]. This drug depletes certain tissues of NE (and other monoamines) by blocking the uptake of the monoamines into the chromaffin storage granules. Reserpine markedly depleted all of the hamster tissues evaluated (including islets) of NE.

There was a correlation between the islet NE concentration and the degree of hyperglycaemia of the hamsters treated with pharmacological agents. This data is compatible with the notion that increased islet NE content may inhibit insulin secretion. However, the plasma insulin concentration was not measured and appropriate control studies of plasma insulin concentrations after glucose-induced hyperglycaemia were not done. Therefore, further studies will be needed to better define the functional role of the increased islet $\mathrm{NE}$ concentration after DOPS administration.

It was previously noted that hamsters fasted $72 \mathrm{~h}$ had a marked decrease of in vivo and in vitro pancreatic insulin secretion [8], and that this decrease was partially prevented by concomitant administration of agents that deplete tissues of monoamines [8]. These pharmacological studies suggested that pancreatic monoamines may play a role in the decreased insulin secretion in the fasting state. Other investigators have reported that the NE concentration of rat hearts is increased during fasting [28].

In the present study no alteration was found in the NE content of hamster pancreatic islets or heart during fasting. Hansen and Hedeskov recently reported that $48 \mathrm{~h}$ of fasting did not alter the NE concentration of mouse islets [19]. The turnover rate of NE was not measured in either the study of Hansen and Hedeskov or in the present study [19]. One might speculate that although the concentration of islet NE did not increase during fasting, the turnover rate of the islet NE did increase. Although they did not measure NE turnover in the pancreatic islets, Young and Landsberg recently noted that there was actually a decreased turnover rate of NE in the heart and acinar pancreas of fasting rats [29, 30]. Further studies will be needed to clarify this point.

Acknowledgements. This study was supported by the Veterans Administration and N1H Chinese Hamster Program Project 08P1 AM 21933A01. We are grateful for the expert secretarial assistance of Mrs. Cynthia Cox.

\section{References}

1. Lebovitz, H. E., Feldman, J. M.: Pancreatic biogenic amines and insulin secretion in health and disease. Fed. Proc. 32, 1797-1802 (1973)

2. Cegrell, L.: The occurrence of biogenic monoamines in the mamalian endocrine pancreas. Acta Physiol. Scand. (Suppl.) 314, 1-60 (1968)

3. Cegrell, L.: Monoaminergic mechanisms in the pancreatic Acells. In: The structures of metabolism of the pancreatic islets. Falkmer, S., Hellman, B., Täljedal, I. B. (Eds.). Oxford: Pergamon Press 1970

4. Quickel, K. E., Jr., Feldman, J. M., Lebovitz, H. E.: Inhibition of insulin secretion by serotonin and dopamine: species variation. Endocrinology 89, 1295-1302 (1971)

5. Esterhuizen, A. C., Spriggs, T. L. B., Lever, J. D.: Nature of islet-cell innervation in the cat pancreas. Diabetes 17, 31-33 (1968)

6. Feldman, J. M., Boyd, A. E. III, Lebovitz, H. E.: Structural determinants of catecholamine action on in vitro insulin release. J. Pharmacol. Exp. Ther. 176, 611-621 (1971)

7. Tjalve, H.: Catechol- and indolamines in some endocrine cell systems. Acta Physiol. Scand. [Suppl.] 360, 8-20 (1971)

8. Feldman, J.M., Lebovitz, H. E.: Role of pancreatic monoamines in the impaired insulin secretion of the fasting state. Endocrinology 92, 1469-1474 (1973)

9. Feldman, J.M., Chapman, B.: Preparation of islets of Langerhans from rabbits and hamsters by the collagenase digestion technique. Acta Diabetol. Lat. 12, 208-218 (1975)

10. Hanks, J. H., Wallace, R. E.: Relations of oxygen and temperature in preservation of tissues by refrigeration. Proc. Soc. Exp. Biol. Med. 71, 196-200 (1949)

11. DaPrada, M., Zurcher, G.: Simultaneous radioenzymatic determination of plasma and tissue adrenaline, noradrenaline and dopamine within the femtomole range. Life Sci. 19, 1161-1174 (1976)

12. Wurtman, R. J., Axelrod, J.: A sensitive and specific assay for the estimation of monoamine oxidase. Biochem. Pharmacol. 12, 1439-1441 (1963)

13. McCaman, R. E.: Microdetermination of catechol-o-methyltransferase in brain. Life Sci. 4, 2353-2359 (1965)

14. Lowry, O. H., Rosenbrough, N. J., Farr, A. L., Randall, R. J.: Protein measurements with the Folin phenol reagent. J. Biol. Chem. 193, 265-275 (1951)

15. Henry, D. P., Starman, B. J., Johnson, D. G., Williams, R. H.: A sensitive radioenzymatic assay for norepinephrine in tissues and plasma. Life Sci. 16, 375-384 (1975)

16. Hellerstrom, C., Brolin, S. E.: Biochemistry and biophysics of insulin secretion. In: Handbook Exp. Pharm. XXXIV-2. Hasselblat, A., Bruchhausen, F.U. (Eds.), pp. 57-78. Berlin, Heidelberg, New York: Springer 1975

17. Saifer, A., Gerstenfeld, B.: Photometric micro determination of blood glucose with glucose oxidase. J. Lab. Clin. Med. 5, 448-460 (1958)

18. Zar, J.H.: Biostatistical analysis, pp. 130-143, 159-161. Englewood Cliffs, N. J.: Prentice-Hall 1974

19. Hansen, S. E., Hedeskov, C. J.: Simultaneous determination of the content of serotonin, dopamine, noradrenaline, and adrenaline in pancreatic islets isolated from fed and starved mice. Acta Endocrinol. (Kbh.) 86, 920-932 (1977)

20. Everett, G. M., Borcherding, J., Morse, P.: Effect of deserpidine and pargyline on the levels of biogenic amines in brain, liver and heart of mice. Res. Commun. Chem. Pathol. Pharmacol. 3, 245-248 (1972)

21. Neff, N. H., Costa, E.: The influence of monoamine oxidase inhibition on catecholamine synthesis. Life Sci. 5, 951-959 (1969) 
22. Lebovitz, H.E., Downs, R. W. Jr.: Catecholamine biosynthesis enzymes in pancreatic islet cells. In: Frontiers in catecholamine research. Usidin, E., Snyder, S. H. (Eds.), pp. 831-833. Oxford: Pergamon Press 1973

23. Corrdi, H., Fuxe, K.: The effect of catecholamine precursors and monoamine oxidase inhibition on the amino levels of central catecholamine neurons after reserpine treatment of tyrosine hydroxylase inhibition. Life Sci. 6, 1345-1350 (1967)

24. Hirai, M., Matsuoka, Y., Nakajima, T., Sano, I.: Effects of 3,4dehydroxyphenylserine on the concentration of brain noradrenaline and the level of plasma growth hormone of rats. Med. J. Osaka Univ. 26, 51-59 (1975)

25. Zern, R. T., Foster, L. B., Blalock, J. A., Feldman, J. M.: Characteristics of the dopaminergic and noradrenergic systems of the pancreatic islets. Diabetes 28, 185-189 (1979)

26. Crout, J. R., Creveling, C. R., Udenfriend, S.: Norepinephrine metabolism in rat brain and heart. J. Pharmacol. Exp. Ther. 132, 269-277 (1961)

27. Baldessarni, R. J., Chace, K. V.: Metabolism of L-DOPA after inhibition of catechol-o-methyltransferase. Eur. J. Pharmacol. 17, 163-166 (1972)
28. Balasubramanian, V., Dhalla, N. S.: Biochemical basis of heart function V: Effect of starvation on storage, transport and synthesis of cardiac norepinephrine in rats. Can. J. Physiol. Pharmacol. 50, 238-243 (1972)

29. Young, J. B., Landsberg, L.: Suppression of sympathetic nervous system during fasting. Science 196, 1473-1475 (1977)

30. Young, J. B., Landsberg, L.: Catecholamines do not mediate the endocrine-metabolic response to fasting in the rat. Clin Res. 25, 404 (Abstract) (1977)

Received: November 10, 1978, and in revised form: April 23, 1979

Jerome M. Feldman, M. D.

Box 2963

Duke University Medical Center

Durham, NC 27710

USA 